\title{
PENGETAHUAN REMAJA PUTRI TENTANG DAMPAK PERNIKAHAN DINI PADA KESEHATAN REPRODUKSI DI SMA BUDAYA BANDAR LAMPUNG
}

\author{
Nurul Isnaini1), Ratna Sari²) \\ ${ }^{1}$ Dosen Fakultas Kedokteran Program Studi Diploma IV Kebidanan Universitas Malahayati. \\ Email: isnaininurul50@yahoo.co.id \\ 2Mahasiswa Program Studi Diploma III Kebidanan Universitas Malahayati. \\ Email: ratnasari@gmail.com
}

\begin{abstract}
Early marriage or young marriage is a marriage performed by a partner or one of their partners is still categorized as a teenager under 19 years. The practice of early marriage is most prevalent in Africa and Southeast Asia. In Southeast Asia, data shows that around 10 million children under the age of 18 are married, while in Africa an estimated $42 \%$ of the child population is married before they are 18 years old. Indonesia is a country with the highest percentage of marriages in the world (ranking 37), and the second highest in ASEAN after Cambodia. The 2013 Riskesdas data showed that the prevalence of the age of first marriage between 15-16 years was 41.9 percent. Nationally, the average age at first marriage in Indonesia is 19.70 percent / year. Lampung BKKBN noted, throughout 2015, as many as 9675 people married underage or under the age of 20 or early marriage.

This study aims to determine the knowledge of young women about the impact of early marriage on reproductive health at Bandar Lampung Cultural High School.

Type of quantitative research, descriptive research design, population of 108 people, sample of 93 people, sampling by random sampling technique, data analysis using univariate analysis.

The results of the univariate analysis found that young women had knowledge about the impact of early marriage on reproductive health, namely 50 respondents (53.8\%) in the good category, 43 respondents (46.2\%) in the poor category. $53.8 \%$.

Young women's knowledge of the impact of early marriage on reproductive health in a good category of
\end{abstract}

Keywords: Knowledge, Early Marriage

\section{ABSTRAK}

Pernikahan dini atau kawin muda sendiri adalah pernikahan yang dilakukan oleh pasangan ataupun salah satu pasangannya masih dikategorikan remaja yang berusia dibawah 19 tahun. Praktik pernikahan usia dini paling banyak terjadi di Afrika dan Asia Tenggara. Di Asia Tenggara didapatkan data bahwa sekitar 10 juta anak usia dibawah 18 tahun telah menikah, sedangkan di Afrika diperkirakan $42 \%$ dari populasi anak, menikah sebelum mereka berusia 18 tahun. Indonesia termasuk negara dengan presentase pernikahan usia muda tertinggi di dunia (ranking 37), dan tertinggi kedua di ASEAN setelah Kamboja. Data Riskesdas 2013 menunjukkan bahwa prevalensi umur pernikahan pertama antara 15-16 tahun sebanyak 41,9 persen. Secara nasional rata-rata usia kawin pertama di Indonesia 19,70 persen/ tahun. BKKBN Lampung mencatat, sepanjang tahun 2015 lalu, sebanyak 9675 masyarakat melakukan pernikahannya di bawah umur atau dibawah usia 20 tahun atau pernikahan dini.

Penelitian ini bertujuan untuk mengetahui pengetahuan remaja putri tentang dampak pernikahan dini pada kesehatan reproduksi di SMA Budaya Bandar Lampung.

Jenis penelitian kuantitatif, rancangan penelitian deskriptif, populasi 108 orang, sampel 93 orang, pengambilan sampel dengan teknik random sampling, analisa data menggunakan analisa univariat.

Hasil analisa univariat didapatkan pengetahuan remaja putri tentang dampak pernikahan dini pada kesehatan reproduksi yaitu sebanyak 50 responden (53.8\%) dalam kategori baik, 43 responden (46.2\%) kategori kurang baik. baik $53.8 \%$.

Pengetahuan remaja putri tentang dampak pernikahan dini pada kesehatan reproduksi dalam kategori 


\section{PENDAHULUAN}

Pernikahan dini atau kawin muda sendiri adalah pernikahan yang dilakukan oleh pasangan ataupun salah satu pasangannya masih dikategorikan remaja yang berusia dibawah 19 tahun (WHO,2013). Pernikahan usia muda merupakan pernikahan remaja dilihat dari segi umur masih belum cukup atau belum matang dimana didalam UU Nomor 1 tahun 1974 pasal 71 yang menetapkan batas maksimum pernikahan diusia muda adalah perempuan umur 16 tahun dan lakilaki berusia 19 tahun itu baru sudah boleh menikah.

Praktek pernikahan usia dini paling banyak terjadi di Afrika dan Asia Tenggara. Di Asia Tenggara didapatkan data bahwa sekitar 10 juta anak usia dibawah 18 tahun telah menikah, sedangkan di Afrika diperkirakan $42 \%$ dari populasi anak, menikah sebelum mereka berusia 18 tahun. Di Amerika Latin dan Karibia, 29\% wanita muda menikah saat mereka berusia 18 tahun. Prevalensi tinggi kasus pernikahan usia dini tercatat di Nigeria (79\%), Kongo (74\%), Afganistan (54\%), dan Bangladesh (51\%). Secara umum, pernikahan anak lebih sering terjadi pada anak perempuan dibandingkan anak laki-laki, sekitar $5 \%$ anak lakilaki menikah sebelum mereka berusia 19 tahun. Selain itu didapatkan pula bahwa perempuan tiga kali lebih banyak menikah dini dibandingkan laki-laki (Hertika, 2017).

Indonesia termasuk negara dengan presentase pernikahan usia muda tertinggi di dunia (ranking 37), dan tertinggi kedua di ASEAN setelah kamboja, pada tahun 2016 terdapat 158 negara dengan usia legal minimum menikah adalah 18 tahun keatas, dan di Indonesia masih diluar itu (Rahmad,2017)

Data Riskesdas 2013 menunjukkan bahwa prevalensi umur pernikahan pertama antara 15-16 tahun sebanyak 41,9 persen. Secara nasional ratarata usia kawin pertama di Indonesia 19,70 persen/ tahun, rata-rata usia kawin didaerah perkotaan 20,53persen/ tahun dan didaerah pedesaan 18,94 persen/tahun, masih terdapat beberapa propinsi rata-rata umur kawin pertama dibawah angka nasional, yaitu provinsi Jambi 19,26persen/ tahun, Lampung 19,38persen/tahun, Banten 19,40persen/ tahun, Jawa Tengah 19,43persen/ tahun, Kalimantan Tengah 19,43persen/ tahun, Bengkulu 19,48persen/ tahun, Nusa Tenggara Barat 19,69persen/tahun, Sulawesi Utara 19,71persen/ tahun, Sumatara Selatan 19,80persen/ tahun, Sulawesi Barat 19,84 tahun, Sulawesi Tengah 19,96 tahun (Riskesdas, 2013).

Analisis survei penduduk antar sensus (SUPAS) 2014, dari Badan Koordinasi Keluarga
Berencana Nasional (BKKBN) didapatkan angka pernikahan diperkotaan lebih rendah dibanding dipedesaan, untuk kelompok umur15-19 tahun perbedaannya cukup tinggi yaitu $5,28 \%$ diperkotaan dan $11,88 \%$ dipedesaan. Hal ini menunjukkan bahwa wanita usia muda diperdesaan lebih banyak yang melakukan pernikahan pada usia muda. Meskipun pernikahan anak merupakan masalah predominan dinegara berkembang, terdapat bukti bahwa kejadian ini juga masih berlangsung dinegara maju yang orang tua menyetujui pernikahan anaknya berusia kurang dari 15 tahun.

Usia kawin pertama yang dilakukan oleh setiap perempuan memiliki resiko terhadap persalinannya. Semakin muda usia kawin pertama seseorang perempuan semakin besarresiko yang dihadapi bagi keselamatan ibu dan anak. Hal ini terjadi karena belum siapnya rahim seorang perempuan usia muda untuk memprodusi anak dan belum siapnya mental dalam rumah tangga (Sistiarani,2008). Penting untuk diketahui bahwa kehamilan pada usia kurang dari 17 tahun meningkatkan risiko komplikasi medis, baik pada ibu maupun pada anak. Kehamilan diusia yang sangat muda ini ternyata berkorelasi dengan angka kematian dan kesakitan ibu. Disebutkan bahwa anak perempuan berusia 10-14 tahun berisiko lima kali lipat meninggal saat hamil maupun bersalin dibandingkan kelompok usia 20-24 tahun, sementara risiko ini meningkat dua kali lipat pada kelompok usia 15-19 tahun. Angka kematian ibu usia dibawah 16 tahun di Kamerun, Etiopia, dan Nigeria, bahkan lebih tinggi hingga enam kali lipat (Fadlyana ,2016)

Anatomi tubuh anak belum siap untuk proses mengandung maupun melahirkan, sehingga dapat terjadi komplikasi berupa obstructedlabour serta obstetric fistula. Data dari UNPFA tahun 2013, memperlihatkan 15\%-30\% diantara persalinan di usia dini disertai dengan komplikasi kronik, yaitu obstetric fistula. Fistula merupakan kerusakan pada organ kewanitaan yang menyebabkan kebocoran urin atau feses kedalam vagina.Wanita berusia kurang dari 20 tahun sangat rentan mengalami obstetric fistula. Obstetric fistula ini dapat terjadi pula akibat hubungan seksual diusia dini (Fadlyana ,2016).

Pernikahan anak berhubungan erat dengan fertilitas yang tinggi,kehamilan dengan jarak yang singkat, juga terjadinya kehamilan yang tidak diinginkan. Mudanya usia saat melakukan hubungan seksual pertama kali juga meningkatkan resiko penyakit menular seksual dan penularan infeksi HIV (Fadlyana ,2016). 
Banyak remaja yang menikah dini berhenti sekolah saat mereka terikat dalam lembaga pernikahan, mereka sering kali tidak memahami dasar kesehatan reproduksi, termasuk di dalamnya risiko terkena infeksi HIV. Infeksi HIV terbesar didapatkan sebagai penularan langsung dari partner seks yang telah terinfeksi sebelumnya. Lebih jauh lagi, perbedaan usia yang terlampau jauh menyebabkan anak hampir tidak mungkin meminta hubungan seks yang aman akibat dominasi pasangan. Pernikahan usia muda juga merupakan faktor risiko untuk terjadinya karsinoma serviks. Keterbatasan pengetahuan dan kurangnya dukungan untuk mendapatkan pelayanan kesehatan karena terbentur kondisi ijin suami, keterbatasan ekonomi, maka penghalang ini tentunya berkontribusi terhadap meningkatnya angka morbiditas dan mortalitas pada remaja yang hamil (Fadlyana ,2016)

Badan Kependudukan Keluarga Berencana Nasional dan Perlindungan Perempuan (BKKBN \& PP) Lampung mencatat, sepanjang tahun 2015 lalu, sebanyak 9675 masyarakat melakukan pernikahannya di bawah umur atau dibawah usia 20 tahun atau pernikahan dini. faktor adanya pernikahan dibawah usia 20 tahun atau pernikahan dini tersebut, disebabkan ketidaktahuan dari pihak orang tua yang memaksakan anaknya untuk menikah dini, serta faktor anak-anak usia dini yangtidak mengetahui dampak pernikahan dini, yang putus sekolah dan tidak memiliki pekerjaan atau kegiatan(Yulmani,2015) Pernikahan dibawah usia 20 tahun ini banyak hal yang akan berakibat buruk bagi para pasangan usia dini itu, seperti diantaranya dari segi kesehatan fisik ibu usia muda rentan dengan fisik yang lemah, apalagi disaat hamil dengan usia muda rentan dengan keguguran, berat badan bayi lahir rendah, pendarahan, kekurangan asupan gizi (B Yulmani,2015).

Sedangkan untuk segi emosional juga sangat riskan dengan perceraian, hal itu disebabkan pengaruh ekonomi yang tidak memiliki pekerjaan dan pengaruh lingkungan atau pergaulan usia muda yang masih ingin bebas sehingga lupa akan tanggung jawabnya sebagai lbu rumah tangga atau kepala rumah tangga, (Yulmani,2015).

Berdasarkan latar belakang diatas, peneliti merasa tertarik untuk meneliti lebih jauh tentang "Pengetahuan Remaja Putri tentang Dampak Pernikahan Dini pada Kesehatan Reproduksi di SMA Budaya Bandar Lampung Tahun 2018".

\section{METODE PENELITIAN}

Jenis penelitian kuantitatif, rancangan penelitian deskriptif, populasi dalam penelitian ini seluruh remaja putrid yang ada di SMA Budaya berjumlah 108 orang, dari populasi yang tersedia diambil sampel dengan menggunakan rumus solvin didapatkan jumlah sampel 93 orang, pengambilan sampel dengan teknik random sampling, penelitian dilakukan pada bulan Juli 2018, analisa data menggunakan analisa univariat.

\section{HASIL DAN PEMBAHASAN}

Analisa Univariat

Tabel 1 Distribusi Frekuensi Umur Remaja Putri Di SMA Budaya

\begin{tabular}{ccc}
\hline Usia & Frekuensi & Persentase $(\%)$ \\
\hline 15 tahun & 22 & 23.7 \\
16 tahun & 41 & 44.2 \\
17 tahun & 25 & 26.9 \\
18 tahun & 5 & 5.4 \\
\hline Total & 93 & 100 \\
\hline
\end{tabular}

Berdasarkan tabel diatas, distribusi frekuensi umur remaja putrid di SMA Budaya yaitu 44.2\% usia 16 tahun, 26.9\% 17 usia 17 tahun, 23.7\% usia 15 tahun, $5.4 \%$ usia 18 tahun.

Berdasarkan tabel dibawah distribusi frekuensi pengetahuan remaja putri tentang dampak pernikahan dini pada kesehatan reproduksi di SMA Budaya yaitu 50 orang (53.8\%) kategori baik, 43 orang $(46.2 \%)$ kategori kurang baik.

Tabel 2 Distribusi Frekuensi Pengetahuan Remaja Putri tentang Dampak Pernikahan Dini pada Kesehatan Reproduksi di SMA Budaya

\begin{tabular}{lcc}
\hline Pengetahuan & Frekuensi & $\begin{array}{c}\text { Persentase } \\
(\%)\end{array}$ \\
\hline Baik & 50 & 53.8 \\
Kurang Baik & 43 & 46.2 \\
\hline \multicolumn{1}{c}{ Total } & 93 & 100 \\
\hline
\end{tabular}

\section{PEMBAHASAN}

Berdasarkan table diatas distribusi frekuensi pengetahuan remaja putri tentang dampak pernikahan dini pada kesehatan reproduksi di SMA Budaya yaitu 50 orang (53.8\%) kategori baik, 43 orang (46.2\%) kategori kurang baik.

Penelitian ini sejalan dengan penelitian yang dilakukan oleh Riska (2012) dengan judul "Gambaran Pengetahuan Remaja Putri Tentang Risiko Pernikahan Dini Terhadap Kehamilan Dan Persalinan Di SMA N 1 Sinjai Utara" Berdasarkan hasil penelitian yang dilakukan di SMA Negeri I Sinjai Utara menunjukkan bahwa dari 97 siswi, terdapat responden $89(91,76 \%)$ yang tahu tentang rsiko pernikahan dini terhadap kehamilan, dan 
responden $8(8,24 \%)$ yang tidak tahu tentang risiko pernikahan dini terhadap kehamilan.

Sejalan dengan teori yang dikemukakan oleh Notoatmodjo (2010) pengetahuan merupakan hasil dari "tahu" dan ini terjadi setelah orang melakukan penginderaan terhadap suatu objek tertentu. Penginderaan terjadi melalui panca indra manusia, yaitu: indra penglihatan, pendengaran, penciuman, rasa dan raba. Sebagian besar pengetahuan manusia diperoleh melalui mata dan telinga, yaitu proses melihat dan mendengar. Selain itu melalui mata dan telinga yaitu proses melihat dan mendengar, selanjutnya proses pengalaman dan proses belajar dalam pendidikan formal maupun informal.

Menurut pendapat penelitian sebagian besar remaja putri berpengetahuan baik, sebanyak 50 responden $(53.8 \%)$ hal ini didapat berdasarkan pengisian kuisioner, hal ini dipengaruhi oleh informasi yang didapat melalui wawancara kepada beberapa remaja putri, pengetahuan baik didapat dari penyuluhan yang diberikan oleh guru selaku pihak sekolah, terkait masa remaja yang sehat dan produktif, penyuluhan yang dilakukan bertemakan tentang kesehatan reproduksi, dan pendidikan seks bagi remaja putri di SMA Budaya Bandar Lampung.

Namun masih terdapat beberapa mahasiswi yang memiliki pengetahuan kurang baik, hal ini dikartenakan status siswi merupakan siswi yang baru masuk sekolah di SMA Budaya, sehingga belum mendapatkan penyuluhan dari pihak sekolah.

\section{SIMPULAN}

Pengetahuan remaja putri tentang dampak pernikahan dini pada kesehatan reproduksi dalam kategori baik $53.8 \%$.

\section{SARAN}

Bagi peneliti selanjutnya untuk dapat melakukan penelitian tentang factor - factor penyebab terjadinya pernikahan dini.

\section{DAFTAR PUSTAKA}

Al Rahmad, A. H. (2017). Pemberian ASI dan MPASI terhadap Pertumbuhan Bayi Usia 6-24 Bulan. Jurnal Kedokteran Syiah Kuala, 17(1), 8-14.

Ana Yusmila. hubungan pengetahuan siswi SMA tentang resiko pernikahan dini dengan kesehatan kehamilan di Langkapura Sumatra Selatan 2008
Fadlyana, E., \& Larasaty, S. (2016). Pernikahan usia dini dan permasalahannya. Sari Pediatri, 11(2), 136-41.

Hertika, P. M., Sulistyorini, L., \& Wuryaningsih, E. W. (2017). Hubungan Pernikahan Usia Dini dengan Risiko Tindak Kekerasan oleh Ibu pada Anak Usia Prasekolah di Kelurahan Sumbersari Kecamatan Sumbersari Kabupaten Jember (The Relation between Early Marriage and the Risk of Abusing by Mothers Towards her Preschoolers. Pustaka Kesehatan, 5(3), 481-488.

Hidayat, A. A. (2007). Metode penelitian kebidanan dan teknik analisis data. Jakarta: salemba medika, 43-44.

Kesehatan, K., \& RI, K. K. (2013). Riset kesehatan dasar. Jakarta: Badan Penelitian dan Pengembangan Kesehatan Departemen Kesehatan Republik Indonesia.

Kusmiran, 2011. Pola Asuh Anak Dan Remaja. . Jakarta : Salemba Medika

Notoatmodjo, Soekidjo (2012). Metodologi Penelitian Kesehatan. Jakarta : PT Rineka Cipta

Notoatmodjo, S. 2016. IImu Perilaku Kesehatan. Jakarta : Rineka Cipta

Notoatmodjo, Soekidjo (2010). Metodologi Penelitian Kesehatan. Jakarta : PT Rineka Cipta

Notoatmodjo, S. 2012. PromosiKesehatan. Jakarta : Rineka Cipta

Romauli S (2012). Kesehatan Reproduksi dan Proses Kehamilan. Jakarta : Salemba Medika

Sibagarian dkk, 2010. Dampak Dan Penanggulangan Kejadian Pernikahan Dini. Nuha Medika : Yogyakarta

Sistiarani, C. (2008). Faktor maternal dan kualitas pelayanan antenatal yang berisiko terhadap kejadian berat badan lahir rendah (BBLR) studi pada ibu yang periksa hamil ke tenaga kesehatan dan melahirkan di rsud banyumas tahun 2008 (Doctoral dissertation, Program Pascasarjana Universitas Diponegoro).

Sugiyono. 2014. Metode Penelitian Kuantitatif kualitatif dan $R \& D$. Bandung : ALFABETA

Yulmaini, S. (2015). Pengembangan Sistem Informasi Geografis Penyebaran Klinik Dan Pengguna Alat Kontrasepsi Di Bandar Lampung. Jurnal Informatika, 14(1), 36-49.

Wawan, A \& Dewi (2009), Pengetahuan, sikap dan perilaku manusia.Yogyakarta :Nuha Medika

Widyastuti (2009). Kesehatan Reproduksi Remaja. Jakarta : Salemba Medika 